\title{
КРАТКНЕ СООБЩЕНИЯ
} BRIEF REPORTS

DOI: 10.29413/ABS.2018-3.4.23

удК 579.61

Ану Д. ' , Хон Сун-Хи ${ }^{2}$, Ии Сан Юн ${ }^{2}$, Ии Уон Жа ${ }^{2}$, Абмэд Д. ', Нямхүу Д. ', Нимадава П. ${ }^{1}$

\section{НОВЫЕ ДАННЫЕ ПО ИССЛЕДОВАНИЮ КЛЕЩЕВЫХ ИНФЕКЦИЙ В МОНГОЛИИ}

\author{
${ }^{1}$ National Center for Communicable Diseases, Ministry of Health of Mongolia \\ (ul. Nam-Yan-Ju, Ulaanbaatar 210648, Mongolia) \\ ${ }^{2}$ Korea Centers for Disease Control and Prevention \\ (187 Osongsaengmyeong 2-ro, Cheongwon-gun, Chungbuk 363-951, Republic of Korea)
}

\begin{abstract}
В работе приведены новые данные о распространённости микроорганизмов, инфищирующих иксодовых клещей в Монголии. Показано, что клещи Dermacentor nuttalli в 96,2-98,7 \% случаев заражены $R$. raoultii. Cреди клещей Ixodes persulcatus заражённость R. raoultii составляет от 78\% до 93,75\%, наличие B. microti при исследовании 97 особей клещей I. persulcatus составило 17,5 \%. Заражённость Canditatus R. tarasevichiae была выявлена в 27,9\% клещей.
\end{abstract}

Ключевые слова: клещевые инфекции, Монголия

Для цитирования: Ану Д., Хон Сун Хи, Ли Сан Юн, Ли Уон Жа, Абмэд Д., Нямхүү Д., Нямадава П. Новые данные по исследованию клещевых инфекций в Монголии. Acta biomedica scientifica, 3 (4), 152-154, DOI 10.29413/ABS.2018-3.4.23.

\section{RECENT STUDIES OF TICK-BORNE INFECTIONS IN MONGOLIA}

Anu D. ', Hong Sung-Hee ${ }^{2}$, Lee Sang-Eun ${ }^{2}$, Lee Won-Ja ${ }^{2}$, Abmed D. ', Nyamkhuu D. ', Nymadawa P. 1

${ }^{1}$ National Center for Communicable Diseases, Ministry of Health of Mongolia (ul. Nam-Yan-Ju, Ulaanbaatar 210648, Mongolia) ${ }^{2}$ Korea Centers for Disease Control and Prevention (187 Osongsaengmyeong 2-ro, Cheongwon-gun, Chungbuk 363-951, Republic of Korea)

We have aimed to detect both Rickettsiae species and Babesia microti in adult ticks of Dermacentor nutalli in Tuv province; and looked for only Rickettsiae species in Ixodes persulcatus in Selenge province. Using the PCR and DNA sequencing techniques, we amplified and sequenced the $16 S$ rRNA, gltA, rOmpA genes of Rickettsia and 18S rRNA gene of B. microti and Rickettsia species were identified. Infection rate for Rickettsiae spp. was 82.7 \% (115/139 samples) by $16 S$ rRNA sequencing results and among them the highest prevalence rate was that for R. raoultii strain $-71.4 \%$ (80/111 samples) by gltA gene sequencing and $100 \%$ (81/81 samples) by rOmpA gene sequencing. Canditatus Rickettsia tarasevichiae strain was detected in $27.9 \%$ (31/11 samples) by gltA gene sequencing. Infection rate for Rickettsiae spp. in D. nutalli ticks was $84.3 \%$ (81/96 samples) and R. raoultii strain comprised 96.2-98.7\% among them. Adult ticks of I. persulcatus were infected with Rickettsiae spp. with $78 \%$ and $93.75 \%$ of them were R. raoultii strain. Seventeen out of 97 ticks (17.5\%) were found to be infected with B. microti. Nucleotide DNA sequencing of partial $18 S$ rRNA and gltA genes supported the PCR results. We have identified that the same species of ticks commonly distributed in Mongolia have been infected with $R$. sibirica, $R$. raoultii and B. microti. It might be the strength of our study as B. microti have not been detected in D. nuttalli ticks yet. We are considering to detect the tick-borne infections in humans.

Key words: tick-borne infections, Mongolia

For citation: Anu D., Hong Sung-Hee, Lee Sang-Eun, Lee Won-Ja, Abmed D., Nyamkhuu D., Nymadawa P. Recent studies of tick-borne infections in Mongolia. Acta biomedica scientifica, 3 (4), 152-154, DOI 10.29413/ ABS.2018-3.4.23.

Начиная с 1998 г. совместно с российскими учёными Института эпидемиологии и микробиологии Восточно-Сибирского научного центра СО РАМН (г. Иркутск), мы проводили комплексные исследования эколого-эпидемиологических и молекулярно-генетических характеристик переносчиков и возбудителей клещевых инфекций в Северной и Центральной Монголии. В результате многолетних совместных экспедиций на территориях природных очагов Монголии, сбора большого количества материалов и лабораторных исследований установлен видовой состав, численность и заражённость клещей, впервые описаны генотипы вируса клещевого энцефалита и боррелий в Монголии, напечатано более 30 работ, подготовлено 2 кандидата наук (Даваажав Абмэд и Жанцандоо Батаа). Наиболее значимые совместные 
результаты опубликованы в высокорейтинговых журналах [1-8]. В настоящей работе представлены краткие результаты исследований иксодовых клещей, проведённых совместно с корейскими специалистами.

\section{МАТЕРИАЛЫ И МЕТОДЫ}

Сбор клещей Ixodes persulcatus проводили в Селенгинским аймаке, Dermacentor nuttalli - в Центральном аймаке. Амплифицированы и секвенированы $16 \mathrm{~S}$ rRNA, gltA, rOmpA гены Rickettsia sp. и гены 18S rRNA Babesia microti.

\section{РЕЗУЛЬТАТЫ И ОБСУЖДЕНИЕ}

Всего было исследовано 97 экземпляров клещей D. nuttalli, 41 экземпляр I. persulcatus на инфицированность Rickettsiae spp. и Babesia spp. Заражённость клещей Rickettsiae spp. составила 82,7 \% (115/139 проб) в ампликонах 16S rRNA, также отмечена высокая заражённость $R$. raoultii (71,4 \%, 80 из 111 проб) при анализе в gltA гене и 100 \% (81/81 проб) rOmpA гене. Canditatus Rickettsia tarasevichiae была выявлена в 27,9 \% (31/11 проб) в gltA гене. Заражённость Rickettsiae spp. клещей D. nuttalli составила 84,3 \% (81/96 проб), R. raoultii - 96,2-98,7 \%. Встречаемость R. raoultii в клещах I. persulcatus составила от 78 \% до 93,75 \%, наличие B. microti при исследовании 97 особей клещей I. persulcatus составило 17,5 \%.

Статья опубликована в рамках международной юбилейной конференции, посвящённой 20-летию научного сотрудничества между Россией и Монголией «Разные страны - общие проблемы природно-очаговых инфекций».

\section{ЛИТЕРАТУРА REFERENCES}

1. Данчинова Г.А., Хаснатинов М.А., Сунцова О.В., Бадуева Л.Б., Горина М.О., Шулунов С.С., Дигас С.Э., Козлова И.В., Верхозина М.М., Черногор Л.И., Арбатская Е.В., Чапоргина Е.А., Беликов С.И., Борисов В.А., Злобин В.И., Абмэд Д., Батаа Ж., Бат-Очир Д., Ценд Н., Нарантуяа Л. Переносчики и возбудители трансмиссивных клещевых инфекций на юге Восточной Сибири и севере Монголии // Бюл. ВСНЦ СО РАМН. 2004. - № 1-3. - С. 107-112.

Danchinova GA, Khasnatinov MA, Suntsova OV, Badueva LB, Gorina MO, Shulunov SS, Digas SE, Kozlova IV, Verkhozina MM, Chernogor LI, Arbatskaya EV, Chaporgina EA, Belikov SI, Borisov VA, Zlobin VI, Abmed D, Bataa Zh, Bat-Ochir D, Tsend N, Narantuyaa L. (2004). Vectors and agents of tick-borne infections in the south of Eastern Siberia and the north of Mongolia [Perenoschiki i vozbuditeli transmissivnykh kleshchevykh infektsiy na yuge Vostochnoy Sibiri i severe Mongolii]. Bulleten' Vostochno-Sibirskogo naucnogo centra, (1-3), 107-112.

2. Данчинова Г.А., Хаснатинов М.А., Злобин В.И., Козлова И.В., Верхозина М.М., Сунцова О.В., Шулунов С.С., Абмэд Д., Батаа Ж., Бат-Очир Д., Цэнд Н., Бадуева Л.Б., Лисак О.В., Горина М.О. Иксодовые клещи юга Восточной Сибири и Монголии и их спонтанная заражённость возбудителями природно-очаговых трансмиссивных инфекций // Бюл. сибирской медицины. - 2006. - Т. 5, № 1. - С. 137-143.
Danchinova GA, Khasnatinov MA, Zlobin VI, Kozlova IV, Verkhozina MM, Suntsova OV, Shulunov SS, Abmed D, Bataa Zh, Bat-Ochir D, Tsend N, Badueva LB, Lisak OV, Gorina MO. (2006). Ixodid ticks of the south of Eastern Siberia and Mongolia and their spontaneous infection with pathogens of tick-borne infections [Iksodovye kleshchi yuga Vostochnoy Sibiri i Mongolii i ikh spontannaya zarazhennost' vozbuditelyami prirodno-ochagovykh transmissivnykh infektsiy]. Byul. sibirskoy meditsiny, 5 (1), 137-143

3. Данчинова Г.А., Хаснатинов М.А., Арбатская Е.В., Шобоева Р.С., Ханхареев С.С., Абмэд Д., Бата Ж., Цэрэнноров Д., Отгонбаатор Д. Распространение клещевых инфекций в бассейне р. Селенга на территории республик Бурятия и Монголия // Бюл. ВСНЦ СО РАМН. 2012. - № 5-1 (87). - С. 206-209.

Danchinova GA, Khasnatinov MA, Arbatskaya EV, Shoboyeva RS, Khankhareyev SS, Abmed D, Bata ZH, Tserennorov D, Otgonbaator D. (2012). Distribution of tick infections in the pool of the Selenga river in the republics of Buryatia and Mongolia [Rasprostranenie kleshchevykh infektsiy v basseyne r. Selenga na territorii respublik Buryatiya i Mongoliya]. Bulleten' Vostochno-Sibirskogo naucnogo centra, (5-1), 206-209.

4. Хаснатинов М.А., Данчинова Г.А., Кулакова H.В., Tungalag К., Арбатская Е.В., Миронова Л.В., Tserennorov D., Bolormaa G., Otgonbaatar D., Злобин B.И. Генетическая характеристика возбудителя клещевого энцефалита в Монголии // Вопросы вирусологии. 2010. - T. 55, № 3. - C. 27-32.

Khasnatinov MA, Danchinova GA, Kulakova NV, Tungalag K, Arbatskaya EV, Mironova LV, Tserennorov D, Bolormaa G, Otgonbaatar D, Zlobin VI. (2010). Genetic characteristics of tick-borne encephalitis virus in Mongolia [Geneticheskaya kharakteristika vozbuditelya kleshchevogo entsefalita v Mongolii]. Voprosy virusologii, 55 (3), 27-32.

5. Fomenko NV, Stronin OV, Goltsova NA, Khasnatinov MN, Danchinova GA, Bataa J. (2009) Heterogeneity of the OspA gene structure from isolates of Borrelia garinii and Borrelia afzelii from Western Siberia and Mongolia. Molecular Genetics, Microbiology and Virology, 24 (4), 183-188.

6. Sabitova Y, Fomenko N, Tikunov A, Stronin O, Khasnatinov M, Abmed D, Danchinova G, Golovljova I, Tikunova N. (2018). Multilocus sequence analysis of Borrelia burgdorferi sensu lato isolates from Western Siberia, Russia and Northern Mongolia. Infect Genet Evol, pii: S1567-1348(18)30193-X. DOI: 10.1016/j. meegid.2018.04.015

7. Khasnatinov M, Tserennorov D, Nymadavaa P, Tchaporgina EA, Glushenkova T, Arbatskaya E, Bataa J, Abmed D, Danchinova GA, Otgonbaatar D. (2010). Tickborne encephalitis virus in Mongolia. Int J Infect Dis, 14 (Suppl. 1), 372-373.

8. Walder G, Orth D, Würzner R, Dierich MP, Lkhamsuren E, Batmunkh T, Shagdar A, Bataa J, Heinz FX, Danchinova GA, Khasnatinov MA. (2006). Serological evidence for tick-borne encephalitis, borreliosis, and human granulocytic anaplasmosis in Mongolia. Int J Med Microbiol, 296 (Suppl. 1), 69-75. 


\section{Сведения об авторах}

Information about the authors

Ану Даваасурэн - врач паразитологической лаборатории, Национальный центр инфекционныхзаболеваний Министерства здравоохранения Монголии (210648, Монголия, Улаанбаатар, ул. Нам-Ян-Жу; тел. +976-11-99188222, факс +976-11-458699; e-mail: anu8222@yahoo.com)

Anu Davaasuren - MD, Doctor at the Parasitologic Laboratory, National Center for Communicable Diseases, Ministry of Health of Mongolia (210648, Mongolia, Ulaanbaatar, ul. Nam-Yan-Ju; tel. 976-11-99188222, fax 976-11-458699; e-mail: anu8222@yahoo. com)

Хон Сун-Хи - научный сотрудник отделения малярии и паразитарных болезней, Корейский национальный институт здравоохранения, Корейский центр по контролю и профилактике заболеваний (187 Osongsaengmyeong 2-ro, Cheongwon-gun, Chungbuk 363-951, тел. +82-43-719-8525, факс +82-43-719-8559)

Hong Sung-Hee - Research Officer, Korea National Institute of Health, Division of Malaria and Parasitic Diseases, Korea Centers for Disease Control and Prevention (187 Osongsaengmyeong 2-ro, Cheongwon-gun, Chungbuk 363-951; tel. +82-43-719-8525, $\mathrm{fax}+82-43-719-8559)$

Ли Сан-Юн - DVM, PhD, научный сотрудник отделения малярии и паразитарных болезней, Корейский национальный институт здравоохранения, Корейский центр по контролю и профилактике заболеваний

Lee Sang-Eun - DVM, PhD, Research Officer, Division of Malaria and Parasitic Diseases, Korea Centers for Disease Control and Prevention

Ли Уон-Жа - директор отдела арбовирусов, Корейский национальный институт здравоохранения, Корейский центр по контролю и профилактике заболеваний (e-mail: wonja@nih.go.kr)

Lee Won-Ja - Director, Division of Arboviruses, Korea National Institute of Health, Korea National Institute of Health, Korea Centers for Disease Control and Prevention (e-mail: wonja@nih.go.kr)

Абмэд Даваажав - кандидат биологических наук, заведующий паразитологической лабораторией, Национальный центр инфекционных заболеваний Министерства здравоохранения Монголии (тел. +976-11-99778211, факс +976-11-458699; e-mail: abmed99@yahoo.com)

Abmed Davvajav - Candidate of Biological Sciences, Head of the Parasitologic Laboratory, National Center for Communicable Diseases, Ministry of Health of Mongolia (tel. +976-11-99778211, fax +976-11-458699; e-mail: abmed99@yahoo.com)

Нямхүу Дулмаа - MD, PhD, профессор, Генеральный директор, Национальный центр инфекционных заболеваний Министерства здравоохранения Монголии (тел. +976-11-99113030, факс +976-11-458699; e-mail: dnyamkhuu_hanui@yahoo.com) Nyamkhuu Dulmaa - MD, PhD, Professor, General Director of the National Center for Communicable Diseases, Ministry of Health of Mongolia (tel. +976-11-99113030, fax +976-11-458699; e-mail: dnyamkhuu hanui@yahoo.com)

Нимадава Пагважав - MD, PhD, доктор медицинских наук, академик, профессор, Заслуженный деятель Здравоохранения Монголии, советник, Национальный центр инфекционных заболеваний Министерства здравоохранения Монголии (тел. +976-11-99112306, факс +976-11-458699; e-mail: nymadawa@gmail.com)

Nymadawa Pagvajav - MD, PhD, Doctor of Medical Sciences, Academician, Professor, Advisor, National Center for Communicable Diseases, Ministry of Health of Mongolia (tel. +976-11-99112306, fax+976-11-458699; e-mail: nymadawa@gmail.com) 